\title{
POLIGAMI PERSPEKTIF TEORI DOUBLE MOVEMENT FAZLUR RAHMAN
}

\section{N. Nafisatur Rofiah}

Pascasarjana IAIN Salatiga, Jawa Tengah, Indonesia

\begin{tabular}{|c|c|}
\hline Article History & \multirow{6}{*}{$\begin{array}{l}\text { ADstract } \\
\text { Writing this scientific article aims to describe polygamy from the } \\
\text { understanding, this theory can provide an explanation to understand and } \\
\text { explore verses } 3 \text { of the suras about polygamy which by the jurists are } \\
\text { considered as the legitimate principle of marriage according to Islam. The } \\
\text { methodology used in writing scientific articles is the research methodology } \\
\text { using the literature review. The literature review is one type of qualitative } \\
\text { research that contains a description of theories, findings, and other } \\
\text { research materials. The primary data source is Fazlur Rahman's works } \\
\text { related to the theory of Double Movement, while other works are used as } \\
\text { secondary data. The method of data collection is documentation and using } \\
\text { content analysis as an analysis. The research findings show that the } \\
\text { importance of understanding the verses of the Qur'an from various } \\
\text { scientific perspectives is needed. Double Movement is a theory carried out } \\
\text { by an interpreter ofthe Qur'an. Using this theory ofDouble Movement that } \\
\text { polygamy is not permissible in our present context. }\end{array}$} \\
\hline Submitted: Dec, 282018 & \\
\hline Accepted : Feb, 142020 & \\
\hline Published : Feb, 172020 & \\
\hline Keywords & \\
\hline & \\
\hline
\end{tabular}

\section{PENDAHULUAN}

Al-Qur'an merupakan bukti kebenaran Nabi Muhammad SAW sekaligus petunjuk untuk umat manusia kapanpun dan di manapun dengan berbagai macam keistimewaan. Keistimewaan tersebut antara lain susunan bahasanya yang unik dan memesona, sifat agung yang tidak seorangpun mampu mendatangkan hal yang serupa, makna-makna yang dapat dipahami oleh siapapun yang memahami bahasanya walaupun tingkat pemahaman mereka berbeda (Shihab, 1999, p. 75).

Mengacu pada perbedaan penafsiran ayat poligami yang terdapat pada surah AnNisa' ayat 3 hingga saat ini masih terjadi kontroversi mengenai boleh dan tidaknya poligami, hal ini menjadi pembahasan yang tidak ada habisnya. Teori Double Movement yang merupakan gagasan pemikiran Fazlur Rahman mengatakan bahwa perlu adanya pemahaman terhadap legal formal dan ideal moral terhadap suatu ayat untuk mendapatkan maksud sesungguhnya dengan keadaan yang dihadapi sekarang. Teori ini hadir dengan dua gerakan yang dilakukan oleh seorang penafsir Al-Qur'an. Tujuannya adalah mengaplikasikan spirit yang disarikan dari konteks diturunkannya ayat untuk diaplikasikan pada konteks kekinian.

Dari penelitian ini diharapkan mampu menjawab kontroversi mengenai boleh dan tidaknya poligami pada kondisi sekarang pespektif Fazlur Rahman dengan teorinya, yakni Double Movement atau teori gerakan ganda. Sehingga masyarakat bisa memahami dengan jelas tentang poligami yang oleh para fuqaha dianggap sebagai asas perkawinan yang sah menurut Islam. 


\section{N. Nafisatur Rofiah}

\section{METODE DAN FOKUS PENELITIAN}

Penulis menggunakan metodologi penelitian literature review, yaitu salah satu jenis penelitian kualitatif yang berisi uraian tentang teori, temuan, dan bahan penelitian lainnya. Sumber data primer adalah karya-karya Fazlur Rahman yang terkait teori Double Movement, sedangkan karya lain dijadikan sebagai data sekunder. Metode pengumpulan data adalah dokumentasi dan menggunakan content analysis sebagai analisa. Dengan harapan, setelah melakukan literature review, penulis tidak berhenti sampai hanya membaca literatur, tetapi juga merangkum, membuat analisis dan melakukan sintesis secara kritis dan mendalam dari sumber-sumber kajian yang direview atau ditinjau.

\section{HASIL DAN PEMBAHASAN}

\section{Biografi Fazlur Rahman}

Fazlur Rahman lahir pada tanggal 21 September 1919, di Hazara (daerah IndiaInggris) yang sekarang Pakistan. Ayahnya bernama Maulana Syahab al-Din dan nama keluarganya adalah Malak. Dia dibesarkan dalam sebuah lingkungan keluarga muslim yang taat, yang mempraktekkan ajaran fundamental Islam seperti, shalat, puasa dan sebagainya. Maka tidak heran jika Rahman pada waktu usia 10 tahun telah berhasil menghafal Al-Qur'an seluruhnya di luar kepala. Orang yang sangat berjasa menanamkan dan membentuk kepribadiannya adalah ayah dan ibunya sendiri. Ayahnya adalah seorang alim yang bermadzhab Hanafi yang berlatarbelakang pendidikan dari Deoband, sebuah madrasah tradisional terkemuka di anak benua IndoPakistan saat itu (Nata, 2013, p. 315).

Ketika Fazlur Rahman berusia 14 tahun keluarganya hijrah ke Lahore, di sana Fazlur Rahman menerima pendidikan modern. Pada tahun 1940, dia menyelesaikan Sarjana Muda (B.A) dalam jurusan Bahasa Arab di Universitas Punjab. Dua tahun kemudian ia memperoleh gelar Master of Art (M.A.) dalam jurusan dan universitas yang sama. Pada tahun 1946 M, ia melanjutkan studi pada program Doctoral (Ph.D Program) di Universitas Oxford, Inggris. Pada program ini Fazlur Rahman berkonsentrasi pada kajian Filsafat Islam. Ia menyelesaikan studi Doktornya dalam waktu 3 tahun (19461949) dengan disertasi yang berjudul Avicenna's Psychology di bawah bimbingan Prof. S. van den Bergh dan H.A.R. Gibb (Nata, 2013, pp. 316-317).

Pada saat kuliah di Oxford ia memiliki kesempatan mempelajari bahasa-bahasa Barat, sehingga ia dapat menguasai bahasa Latin, Yunani, Inggris, Jerman, Turki, Arab, dan Urdu. Hal itu sangat berguna dalam memperdalan dan memperluas keilmuannya, terutama dalam studi-studi islam melalui penelusuran literatur-literatur keislaman yang ditulis para orientalis dalam bahasa-bahasa mereka. Dengan pengalamannya, ia tidak bersikap apologetik, tetapi justru lebih memperlihatkan penalaran objektif.

Setelah selesai kuliah di Oxford University, ia tidak langsung pulang ke negerinya, Pakistan. Ia mengajar beberapa tahun di Durham University, Inggris. Selanjutnya di Institute of Islamic Studies, McGill University, Kanada. Ketika di Durham University dia berhasil menyelesaikan karya orisinilnya dengan judul Prophecy in Islam: Philosophy and Orthodoxy. Pada tahun 1960-an Rahman pulang ke negerinya, Pakistan. 
Dua tahun kemudian dia ditunjuk sebagai Direktur Lembaga Riset Islam setelah sebelumnya menjabat sebagai staf di lembaga tersebut. Selama kepemimpinannya lembaga ini berhasil menerbitkan dua jurnal ilmiah, Islamic Studies dan Firk u-Nazr (berbahasa Urdu). Pada tahun 1964, Rahman ditunjuk sebagai anggota Dewan Penasihat Ideologi Islam Pemerintah Pakistan setelah beberapa saat sebelumnya dia melepaskan jabatannya selaku Direktur Lembaga Riset Islam (Nata, 2013, p. 317).

Setelah melepas kedua jabatannya di Pakistan, Rahman hijrah ke Barat. Dia diterima sebagai tenaga pengajar di Univesitas California, Los Angeles, Amerika Serikat. Kemudian pada tahun 1969 dia menjabat sebagi Guru Besar Kajian Islam dalam berbagai aspeknya di Departement of Near Eastern Languages and Civilization, University of Chicago.

Rahman menetap di Chicago kurang lebih selama 18 tahun, sampai meninggal dunia pada 26 Juli 1988. Jauh sebelum wafat dia memang telah mengidap diabetes yang kronis, yang memaksanya menyuntikkan diri setiap hari. Tetapi yang membawa ajalnya ialah serangan jantung yang berat sehingga harus dioperasi. Meskipun operasinya berjalan dengan lancar, setidaknya untuk beberapa minggu hingga ajal menjemputnya (Amal, 1990, p. 111).

Selain memberi kuliah, Rahman juga sering diminta oleh pusat studi terkemuka di Barat untuk memberi kuliah-kuliah atau berpartisipasi dalam seminar-seminar internasional yang berkajian keislaman. Misalnya Pusat Studi-studi Yahudi Universitas Connecticut di Storrs memintanya pada musim semi 1981 untuk memberi kuliah tentang sikap Islam terhadap agama Yahudi. Demikian juga Universitas PBB mengundangnya untuk menyampaikan kertas kerja dalam seminar "Perceptions of Desirable Society", yang diselenggarakan di Bangkok 12-15 Maret 1985. Bahkan bersama Prof. Sherif Mardin dari Istanbul (1985), dia diundang ke Indonesia untuk membantu meninjau dan memberi advis terhadap operasi-operasi IAIN (Amal, 1990, p. 105-106).

Sebagai pemimpin berbagai proyek penelitian universitas tersebut. Salah satu proyek yang dipimpin bersama-sama dengan Prof. Dr. Leonard Binder yakni tentang Islam dan perubahan sosial yang melibatkan banyak sarjana junior. Riset tersebut berpusat pada lima masalah pokok, yaitu pendidikan agama dan perubahan peran ulama dalam Islam; syariah dan kemajuan ekonomi; keluarga dalam masyarakat dan hukum Islam masa kini; Islam dan masalah legalitas politik, serta perubahan konsep stratifikasi di dalam masyarakat muslim masa kini. Riset ini dilakukan di Pakistan, Mesir, Turki, Iran, Maroko dan Indonesia.

\section{Fazlur Rahman: Double Movement}

Double Movement merupakan metode yang memberikan pemahaman yang sistematis dan kontekstualis, sehingga menghasilkan suatu penafsiran yang mampu menjawab persoalan-persoalan kekinian. Adapun yang dimaksud dengan gerakan ganda adalah: dimulai dari situasi sekarang ke masa Al-Qur'an diturunkan dan kembali lagi ke masa kini (Rahman, 1982, p. 6).

Al-Qur'an adalah respons Illahi melalui ingatan dan pikiran Nabi Muhammad, kepada situasi moral-sosial masyarakat Arab pada masa Nabi. Artinya, signifikansi 


\section{N. Nafisatur Rofiah}

pemahaman setting-social Arab pada masa Al-Qur'an diturunkan disebabkan adanya proses dialektika antara Al-Qur'an dengan realitas, baik itu dalam bentuk tahmil (menerima dan melanjutkan), tahrim (melarang keberadannya), dan taghiyyur (menerima dan merekontruksi tradisi) (Sodiqin, 2008, pp. 116-117).

Gerakan pertama, bertolak dari situasi kontemporer menuju ke era Al-Qur'an diwahyukan, dalam pengertian bahwa perlu dipahami arti dan makna dari suatu pernyataan dengan cara mengkaji situasi atau problem historis di mana pernyataan AlQur'an tersebut hadir sebagai jawabannya. Dengan kata lain, memahami Al-Qur'an sebagai suatu totalitas selain sebagai ajaran-ajaran spesifik yang merupakan respons terhadap situasi-situasi spesifik. Kemudian, respon-respon yang spesifik ini digeneralisir dan dinyatakan sebagai pernyataan-pernyataan yang memiliki tujuantujuan moral umum yang dapat "disaring" dari ayat-ayat spesifik yang berkaitan dengan latar belakang sosio historis dan rasio legis yang sering diungkapkan. Selama proses ini, perhatian harus diberikan pada arah ajaran Al-Qur'an sebagai suatu totalitas sehingga setiap arti atau makna tertentu yang dipahami, setiap hukum yang dinyatakan, dan setiap tujuan atau sasaran yang diformulasikan akan berkaitan dengan lainnya. Singkatnya, dalam gerakan pertama ini, kajian diawali dari hal-hal yang spesifik dalam Al-Qur'an, kemudian menggali dan mensistematisir prinsip-prinsip umum, nilai-nilai dan tujuan jangka panjangnya (Sholeh, 2007, p. 132).

Gerakan kedua, dari masa Al-Qur'an diturunkan (setelah menemukan prinsip prinsip umum) kembali lagi ke masa sekarang. Dalam pengertian bahwa ajaran-ajaran (prinsip) yang bersifat umum tersebut harus ditubuhkan dalam konteks sosio-historis yang konkret di masa sekarang. Untuk itu perlu dikaji secara cermat situasi sekarang dan dianalisa unsur-unsurnya sehingga situasi tersebut dapat dinilai dan diubah sejauh yang dibutuhkan serta ditetapkan prioritas-prioritas baru demi mengimplementasikan nilai-nilai Al-Qur'an secara baru pula. Gerakan kedua ini juga akan berfungsi sebagai pengoreksi dari hasil-hasil pemahaman dan penafsiran yang dilakukan pada gerakan pertama. Karena jika hasil-hasil pemahaman itu tidak bisa diterapkan dalam masa sekarang, itu artinya telah terjadi kegagalan dalam menilai situasi sekarang dengan tepat atau kegagalan dalam memahami Al-Qur'an. Mustahil bahwa sedalam tatanan secara spesifik (masyarakat Arab) pada masa lampau tidak bisa direalisasikan dalam konteks sekarang. Ini dilakukan dengan jalan mempertimbangkan perbedaan "dalam hal-hal yang spesifik yang ada pada situasi sekarang” yang mencakup baik pengubahan aturan-aturan pada masa lampau sehingga selaras dengan tuntutan situasi sekarang (sejauh tidak melanggar prinsip-prinsip umum pada masa lampau) maupun mengubah situasi sekarang sepanjang diperlukan hingga sesuai dengan prinsip-prinsip umum tersebut (Sibawaihi, 2007, pp. 59-60).

Fazlur Rahman selanjutnya meyakinkan bahwa apabila kedua moment gerakan ganda ini berhasil diwujudkan, niscaya perintah-perintah Al-Qur'an akan menjadi hidup dan efektif kembali. Oleh karena itu, kelancaran tugas yang pertama sangat bergantung dan berhutang budi pada kerja para sejarawan. Sementara tugas yang kedua, meskipun sangat memerlukan instrumentalitas para saintis sosial (sosiolog dan antropolog), demi menentukan "orientasi efektif" dan "rekayasa etis", maka kerja para penganjur moral (ulama) lah yang diandalkan (Sholeh, 2007, p. 133). 


\section{Poligami: Double Movement}

Kata "poligami" secara etimologi berasal dari bahasa Yunani yaitu polus yang berarti banyak dan gamos yang berarti perkawinan. Bila pengertian kata ini digabungkan, maka poligami akan berarti suatu perkawinan yang banyak atau lebih dari seorang. Dalam Kamus Besar Bahasa Indonesia, poligami yaitu adat seorang laki-laki beristri lebih dari seorang, dan poliandri adalah adat seorang perempuan bersuami lebih dari seorang (Poerwadarminta, 2006, p. 906).

Firman Allah dalam surat An-Nisa' ayat 3:

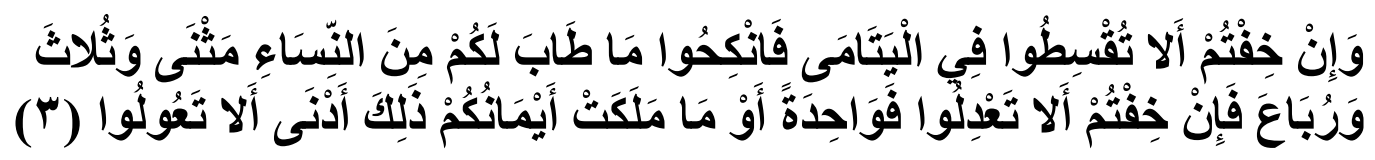

"Dan jika kamu takut tidak akan dapat berlaku adil terhadap (hak-hak) perempuan yang yatim (bilamana kamu mengawininya), Maka kawinilah wanita-wanita (lain) yang kamu senangi: dua, tiga atau empat. Kemudian jika kamu takut tidak akan dapat berlaku adil, Maka (kawinilah) seorang saja, atau budak-budak yang kamu miliki. Yang demikian itu adalah lebih dekat kepada tidak berbuat aniaya."

Gerakan yang pertama dilakukan untuk melihat konteks diturunkannya AnNisa' ayat 3, dengan tujuan untuk menangkap spirit atau pesan yang ingin disampaikan dalam ayat tersebut. An-Nisa' ayat 3 diturunkan setelah Perang Uhud, di mana kaum Muslim mengalami kekalahan. Banyak para sahabat laki-laki yang meninggal pada perang tersebut sehingga meninggalkan istrinya menjadi janda dan anaknya menjadi yatim. Padahal mereka tidak terbiasa mengelola harta mereka. Untuk itu Nabi menugaskan sebagian sahabat yang hidup untuk mengurusi harta anak yatim. Namun sebagian sahabat tersebut tidak menjalankan amanahnya. Di antara mereka ada yang menukar harta milik anak yatim itu, yang baik milik anak yatim dia tukar dengan yang buruk milik sahabat pengelola harta tersebut. Sebagian dari mereka juga memakan harta milik anak yatim yang berada dalam asuhannya, seakan itu adalah harta miliknya sendiri. Anak yatim yang dikelola hartanya mungkin tidak tahu apa yang sudah dilakukan sahabat pengelola hartanya. Namun Allah Maha Tahu. Allah menegur perbuatan sahabat tersebut dalam An-Nisa' ayat 4 berikut ini:

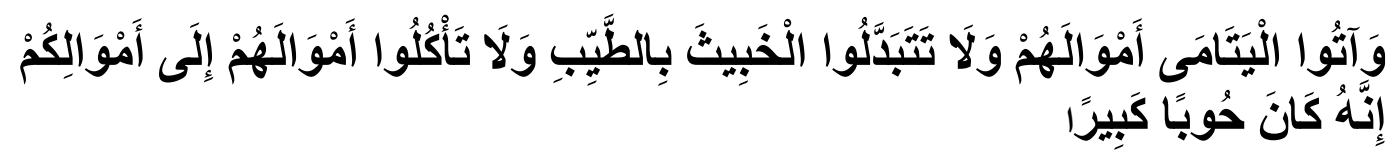

"Dan berikanlah kepada anak-anak yatim (yang sudah balig) harta mereka, jangan kamu menukar yang baik dengan yang buruk dan jangan kamu makan harta mereka bersama hartamu. Sesungguhnya tindakan-tindakan (menukar dan memakan) itu, adalah dosa yang besar".

Berdasarkan ayat tersebut Allah menegur sahabat tersebut untuk memberikan harta milik anak yatim dan tidak menukar yang buruk dengan yang baik serta tidak memakan harta anak yatim dengan mencampurkannya dengan harta para sahabat pengelola, karena itu merupakan dosa besar. Sebagian sahabat yang diberi amanat tersebut juga tertarik untuk menikahi anak yatim yang berada di bawah asuhannya 


\section{N. Nafisatur Rofiah}

karena mereka tertarik terhadap kecantikan anak yatim tersebut dan karena ingin memiliki hartanya. Sayangnya mereka enggan membayar mas kawin yang layak terhadap anak yatim.

Dari ayat di atas dapat diketahui bahwa jika para sahabat pengelola harta anak yatim itu khawatir tidak dapat berlaku adil [dengan membayar mahar yang layak/seharusnya] kepada anak yatim, maka Allah menganjurkan untuk menikahi perempuan lain [yang bukan yatim], dua, tiga atau empat. Dengan menikahi perempuan lain, mungkin sahabat tersebut dapat lebih berbuat adil dengan membayar mahar yang layak karena jika ia tidak membayar mahar yang layak, perempuan tersebut mungkin akan menyatakan ketidak setujuannya pada ayahnya yang kemudian ayahnya mungkin menegur sahabat tersebut untuk membayar maharnya dengan layak. Sementara anak yatim tidak lagi memiliki pelindung tempatnya mengadu jika ia tidak setuju terhadap pembayaran mahar yang tidak layak tersebut. Namun menikahi perempuan lebih dari satu pun ada syaratnya, yaitu harus berlaku adil. Jika tidak dapat berlaku adil, maka dianjurkan menikahi satu perempuan saja atau jika ingin hanya mengeluarkan mahar setengah dari selayaknya maka dianjurkan menikahi budak yang dimilikinya karena budak memang dianggap layak menerima mahar setengah dari mahar untuk perempuan yang merdeka. Adil yang disyaratkan dalam menikahi perempuan lebih dari satu itu disebutkan dalam An-Nisa' ayat 129 tidak mungkin dapat tercapai walaupun laki-laki tersebut menginginkannya:

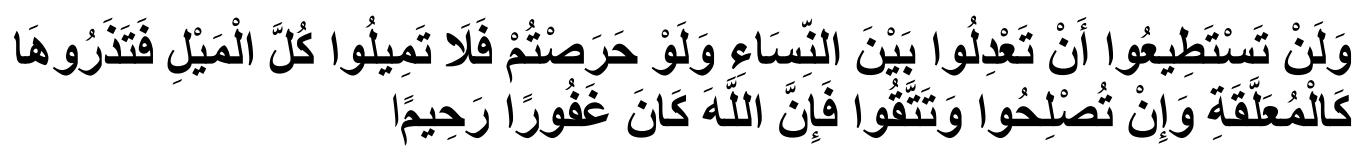

"Dan kamu sekali-kali tidak akan dapat berlaku adil di antara isteri-isteri(mu), walaupun kamu sangat ingin berbuat demikian, karena itu janganlah kamu terlalu cenderung (kepada yang kamu cintai), sehingga kamu biarkan yang lain terkatungkatung. Dan jika kamu mengadakan perbaikan dan memelihara diri (dari kecurangan), maka sesungguhnya Allah Maha Pengampun lagi Maha Penyayang”.

Dari uraian di atas, apa spirit yang dapat disarikan dari An-Nisa' ayat 2-3 dan 129? Apakah benar ayat tersebut memberikan legitimisi atau membolehkan poligami seperti yang diklaim para pendukung poligami? Dari uraian di atas dapat disarikan bahwa spirit atau the intended message dari ketiga ayat tersebut adalah pentingnya penegakan keadilan, terutama bagi kelompok rentan seperti anak yatim, bukan tentang pembolehan poligami karena poligami sudah biasa dilakukan jauh sebelum datangnya Islam. Sebelum datangnya Islam, orang Arab sudah biasa berpoligami, tanpa batas jumlah istri yang boleh dinikahi dan tanpa ada aturan harus berbuat adil. An-Nisa ayat 3 juga dapat dipahami sebagai revolusi Islam terhadap budaya poligami Jahiliyah agar pernikahan itu monogami, karena dengan bermonogami akan lebih memungkinkan untuk tidak berbuat aniaya (tidak berlaku tidak adil).

Setelah menemukan spirit dari An-Nisa' ayat 2-3 dan 129, yaitu tentang pentingnya penegakan keadilan, terutama bagi kelompok rentan seperti anak yatim, maka dapat dilakukan gerakan yang kedua yaitu kembali ke masa sekarang untuk mengaplikasikan spirit tersebut dalam konteks kekinian. Jika pada masa turunnya ayat saja sudah disebutkan dalam An-Nisa' ayat 129 bahwa seorang laki-laki itu tidak akan 
pernah bisa berbuat adil terhadap lebih dari satu perempuan dan adil merupakan syarat dari menikahi perempuan lebih dari satu, maka dapat disimpulkan bahwa menikah lebih dari satu itu tidak diperbolehkan.

Dari agama yang ada, hanya Islam yang secara tegas menganjurkan menikahi satu perempuan. Menikahi perempuan satu, atau monogami, akan lebih memungkinkan mencapai tujuan pernikahan seperti yang termaktub dalam Ar-Rum ayat 21, yaitu untuk mencapai keluarga yang sakinah mawaddah wa rahmah.

\section{PENUTUP}

Teori Double Movement merupakan teori yang terdiri dari dua gerakan. Pertama, dari yang khusus (particular) kepada yang umum (general). Kedua, ajaran-ajaran (prinsip) yang bersifat umum tersebut harus disatukan dalam konteks sosio-historis yang kongkrit di masa sekarang. Untuk itu perlu dikaji secara cermat situasi sekarang dan dianalisa unsur-unsurnya sehingga situasi tersebut dapat dinilai dan diubah sejauh yang dibutuhkan serta ditetapkan prioritas-prioritas baru demi mengimplementasikan nilainilai Al-Qur'an secara baru pula.

Fazlur Rahman berpandangan bahwa poligami itu terlarang untuk diaplikasikan hari ini, sebagaimana teori Double Movement-nya yang pada intinya mengatakan bahwa hal terpenting dalam memahami suatu ayat adalah mengetahui legal formal (makna tersurat ayat) dan ideal moral (cita-cita yang diharapkan dalam suatu ayat/maksud sesungguhnya dari suatu ayat). Menurut teori ini, ideal moral dari ayat poligami adalah monogami.

\section{REFERENSI}

Nata, Abuddin. (2013). Pemikiran Pendidikan Islam E Barat. Jakarta: Rajawali Pers.

Poerwadarminta, W.J.S. (2006). Kamus Umum Besar Bahasa Indonesia. Edisi ketiga. Jakarta: Balai Pustaka.

Rahman, Fazlur. (1982). Islam and Modernity: Tranformation of an Intellectual Tradition. Chicago: Chicago University Press.

Rahman, Fazlur. (1996). Tema Pokok Al-Qur'an. (Anas Mahyuddin, transl). Bandung: Pustaka.

Rahman, Fazlur. (2000). Gelombang Perubahan dalam Islam. (Aam Fahmia, transl). Jakarta: PT RajaGrafindo Persada.

Shihab, Quraish. 1999. Membumikan Al-Qur'an: Fungsi dan Peran Wahyu Dalam Kehidupan Masyarakat. Bandung: Mizan.

Sholeh, Ahmad Syukri. (2007). Metodologi Tafsir Al-Qur'an Kontemporer dalam Pandangan. Jakarta: Gaung Persada Press.

Sibawaihi. (2007). Hermeneutika Al-Qur'an Fazlur Rahman. Yogyakarta: Jalasutra. 